\title{
Psychologia muzyki i muzykoterapia - przedmiot, klasyfikacja, relacja
}

\begin{abstract}
The text is focused on two relatively young yet rapidly developing disciplines: psychology of music and music therapy. The goal of the article was to outline the territories of both disciplines and consider relationships between them. The text includes characteristics, presented through clarification of the subjects of both areas, attempt to place them in the general classification of sciences and considerations regarding the methodology. It also indicates important aspect of artistic component, present especially in practical music therapy, and reaching beyond scientific inquiry. The author notices difficulties of integrating activities utilizing arts with systematic, research-oriented perspective. She shows relationships between disciplines, paying attention to the significant differences, but also complementary values. She concludes that despite of being separate, psychology of music and music therapy have common grounds.
\end{abstract}

\section{Keywords:}

music therapy, psychology of music, interdisciplinary relationships

${ }^{1}$ Ludwika Konieczna-Nowak, Zakład Muzykoterapii, Katedra Pedagogiki Muzyki, Wydział Kompozycji, Interpretacji, Edukacji i Jazzu, Akademia Muzyczna im. Karola Szymanowskiego w Katowicach, Polska, lkonieczna@yahoo.com. 


\section{WSTĘP}

Muzyka jest zjawiskiem fascynującym i wysoce złożonym. Stwierdzenie to, wbrew pozorom, nie jest zupełnie trywialne. Zwraca uwagę na dwa elementy, leżące u podstaw związanego z muzyką bogatego dorobku myślowego człowieka: od literatury pięknej, poprzez traktaty teoretyczne będące częścią historii estetyki, filozoficzne rozważania próbujące uchwycić istotę fenomenu, refleksje nad społeczną rolą, po osiągnięcia akustyki czy najnowsze badania dotyczące aktywności mózgu podczas słuchania i tworzenia muzyki. Pierwszy ze wspomnianych elementów to fascynacja i poruszenie, które budzi sztuka dźwięków, stające się motorem prób rozwiązania jej zagadki, będących udziałem przedstawicieli różnych dyscyplin. Drugi - to złożoność, zarówno muzyki samej w sobie, jak i jej istnienia w szerokim kontekście egzystencji człowieka.

Muzyka, jako jedno z ważnych ludzkich doświadczeń, jest zatem przedmiotem refleksji mogącej wynikać z zupełnie odmiennych perspektyw: artysty, filozofa, naukowca. Podążając tym tropem, inaczej patrzy na nią (czy raczej - słucha jej) psycholog, socjolog, lekarz czy fizyk. Urzeczeni jej niezwykłością przedstawiciele kolejnych nauk dokonują spostrzeżeń zakorzenionych w odmiennych nurtach myślowych, w innych kontekstach, zakładając sobie rozmaite cele. Jedni próbują zrozumieć ją lepiej poprzez rozłożenie na „czynniki pierwsze” i poznanie natury elementów składowych; inni twierdzą, że jedynie holistyczny, całościowy ogląd umożliwia jej poznanie. Nie sposób byłoby przytoczyć tutaj kompletnego obrazu współczesnej, a tym bardziej historycznej refleksji nad muzyką. Ze względu na profil niniejszego tekstu wspomniane zostaną jedynie wybrane perspektywy, pozostające w związku z głównym tematem rozdziału, czyli relacjami pomiędzy stosunkowo bliskimi sobie dyscyplinami, jakimi są psychologia muzyki i muzykoterapia.

Dyscypliny te, dzielące w znacznej mierze obszary znajdujące się w centrum zainteresowań, charakteryzuje jednak odmienny sposób patrzenia na nie. W bieżącym tekście poddane zostaną porównaniu w odniesieniu do kilku wymiarów. Niewątpliwie „człowiek” i „muzyka” stanowić będą ich podstawę. Zarówno pierwiastek ludzki, jak i artystyczny psychologia muzyki i muzykoterapia postrzegają nieco inaczej. Nie mniej istotnym wymiarem będzie określenie pozycji dyscyplin w klasyfikacji nauk. Wreszcie - usytuowanie ich w relacji nie tylko do nauki, lecz także ogniskującej naukową refleksję sztuki, również w obliczu praktycznym. 


\section{MUZYKA JAKO PRZEDMIOT REFLEKSJI}

Mnogość perspektyw oraz interdyscyplinarność obecną w opisie muzyki ujawnia współczesne piśmiennictwo naukowe, ukazujące ją w odmiennych odsłonach, akcentując poszczególne jej aspekty, rzucając na odległe tła. Fizyczną naturę dźwięku zgłębiano od starożytności dziś dźwięk, będący w centrum zainteresowania akustyki, analizowany jest przy udziale zaawansowanych technologii (Johnston, 2002). Refleksję socjologiczną odnaleźć można w opracowaniach ogólnych, omawiających między innymi związek nauk społecznych z muzyką, a także społeczne determinanty doświadczenia muzycznego (Silbermann, 1998). Przede wszystkim jednak fenomen sztuki dźwięków w kontekście społecznym badany jest w precyzyjniej określonych aspektach, gdy pod lupę brane są relacje muzyki z wybranymi zagadnieniami, jak na przykład: muzyka a narodowość (Curtis, 2008), muzyka i rasa (Brown, 2007). W pracach zgłębiających tę tematykę kontekst socjologiczny współistnieje ściśle $\mathrm{z}$ antropologicznym, historycznym, muzykologicznym i psychologicznym. Wielowymiarowość i usytuowanie pomiędzy dyscyplinami nieodzowne są także w etnomuzykologicznych rozważaniach dotyczących muzyki i konfliktu (O’Connel, Castello-Branco, 2010) czy muzyki i manipulacji (Brown, 2006). Zjawiska związane z odbiorem i twórczością muzyczną poddawane są badaniom biologów i neurobiologów, analizujących mechanizmy tych procesów na poziomie reakcji fizjologicznych organizmu, odbioru bodźców zmysłowych i aktywności ludzkiego mózgu. W ten sposób bada się związki elementów muzycznych z innymi, pozamuzycznymi działaniami i doświadczeniami człowieka, jak na przykład ruch, język, odczuwanie emocji (Thaut, 2008; Patel, 2008; Zatorre, Peretz, 2001).

\section{PSYCHOLOGIA MUZYKI I MUZYKOTERAPIA - CHARAKTERYSTYKA DYSCYPLIN}

Psychologia jako nauka zajmująca się mechanizmami psychicznymi do ogromu podejmowanych wątków zalicza także szeroko pojęte doświadczenia związane z muzyką. Zważywszy na wewnętrzne zróżnicowanie dyscypliny, w samych jej ramach odnaleźć można bardzo różne interpretacje miejsca i charakteru funkcjonowania sztuki dźwięków. Zainteresowanie muzyczną aktywnością człowieka doprowadziło do narodzin węższej, wyspecjalizowanej dziedziny - psychologii muzyki. Wierszyłowski (1979) stwierdza, że zakresu dyscypliny nie da się ściśle określić ze względu na szerokość problematyki muzycznej w kontekście rozwoju 
i zmienności egzystencji człowieka. W jego opinii „psychologia muzyki staje się nauką o coraz rozleglejszej problematyce, obejmując swym zasięgiem nie tylko odbiorcę muzyki, kompozytora, wykonawcę, ale także wiele innych dziedzin, takich jak wychowawcze, rekreacyjne i lecznicze funkcje muzyki, rozwój zdolności muzycznych czy formowanie gustów” (s. 18). Psychologia muzyki nie jest jednak jedyną dziedziną eksplorującą podobne obszary. Nauczaniem muzyki i wspomaganiem rozwoju talentów zajmuje się edukacja muzyczna; żywo rozwija się także muzykoterapia, czerpiąca z terapeutycznego potencjału muzyki. Pogląd Wierszyłowskiego (1979) może budzić wątpliwości i pytania: jeśli psychologia muzyki bada lecznicze funkcje muzyki, jaki jest jej związek ze wspomnianą, stosunkowo młodą dyscypliną naukową - muzykoterapią? Czy podział między nimi jest uzasadniony? Dzięki dystansowi czasowemu, jaki dzieli pracę Wierszyłowskiego od niniejszego opracowania, stwierdzić można, że rozwój obu dyscyplin przybrał odmienne kierunki. Bieżący tekst stanowić będzie próbę odpowiedzi na postawione wyżej pytania, z uwzględnieniem obecnego stanu wiedzy.

Przytoczone wcześniej treści rzuciły już pewne światło na wieloaspektowość refleksji nad muzyką. Dyscypliny, których dotyczy niniejszy tekst do pozostają w stosunkowo bliskiej relacji z każdą ze wspomnianych perspektyw: fizyczną, socjologiczną, antropologiczną, muzykologiczną, biologiczną i psychologiczną. Interakcja między tymi naukami w zakresie badania twórczości i percepcji muzycznej, zarówno w jednostkowym, jak i ogólnym wymiarze, jest nieodzownym składnikiem wszelkich rozważań dotyczących tej tematyki; pozostają one w swego rodzaju symbiozie, czerpiąc wzajemnie ze swoich dokonań, wzbogacając się wielostronnie. Do nauk tych odwołują się zarówno psycholodzy muzyki, jak i muzykoterapeuci, nierzadko na ich podwalinach tworząc własne, wyspecjalizowane teorie czy prowadząc szczegółowe badania.

Psychologia muzyki wyrosła z gruntu psychologii ogólnej. Nieodłącznym elementem muzykoterapii jest aspekt terapeutyczny (psychoterapeutyczny, leczniczy, wspomagający), także z psychologią ściśle związany. Zatem wspólną płaszczyznę dla tych dyscyplin tworzy nie tylko muzyka, lecz także wiedza psychologiczna. Podobnie, wątkiem interesującym dla obu nauk jest edukacja muzyczna, łącząca się z osiągnięciami pedagogiki. Zarówno psychologia muzyki, jak i muzykoterapia pozostają także niewątpliwie w bliskiej relacji z teorią muzyki i muzykologią. Istnieją jednak dziedziny, które, ze względu na praktyczne ukierunkowanie i kontekst, zdecydowanie bardziej wpływają na muzykoterapię niż psychologię muzyki. To te, które obejmują wszelkie zagadnienia związane z odbiegającym od szeroko pojętych norm, zdrowotnych czy społecznych, funkcjonowaniem człowieka, czyli: medycyna, psychoterapia czy specjalizacje pedagogiczne. 
Co do różnic między wybranymi dyscyplinami, wydaje się, że dotyczą one przede wszystkim sposobu i celu funkcjonowania psychologii muzyki i muzykoterapii oraz w ich stosunku do sztuki. Psychologia muzyki jest przede wszystkim dyscypliną akademicką. Określenie „muzykoterapia” natomiast wiąże się głównie z profesją, aktywnością bezpośrednio wspierającą funkcjonowanie jednostek. Obok niej, czy raczej wspólnie z nią rozwija się nauka konstytuująca jej podłoże teoretyczne. „Pod terminem muzykoterapia rozumieć można tak praktyczną działalność, jak też i wiedzę i naukę o niej, zajmującą się teorią muzykoterapii” - pisze Natanson (1979, s. 51). Jednocześnie w tej właśnie praktycznej działalności wymagana jest umiejętność tworzenia, aktywność artystyczna, nie naukowa, niemająca zastosowania w psychologii muzyki, badającej tę samą twórczość, ale z dystansu.

By nakreślić bliżej zależności istniejące pomiędzy psychologią muzyki i muzykoterapią, celowe wydaje się przytoczenie ogólnych ich definicji, wskazujących na przedmiot i zadania tych nauk.

\subsection{PSYCHOLOGIA MUZYKI}

Psychologia muzyki zajmuje się szeroko pojętym istnieniem muzyki w życiu człowieka. W opinii Seashore’a (1967), jednego z pionierów tej dyscypliny, twórczość muzyczna staje się elementem stanowiącym punkt wyjścia dla rozważań dotyczących jej jako ekspresji oraz jako bodźca wyzwalającego odczucia. Określając przedmiot psychologii muzyki odwołuje się do trzech podstawowych kategorii, jakimi są wykonawca, muzyka i słuchacz, oraz do tego, co się z nimi wiąże (s. 24). Z kolei Danecka-Szopowa (1960, s. 6) stwierdza, że „przedmiotem psychologii muzyki jest człowiek rozpatrywany pod kątem jego stosunku do muzyki. Ściślej określając, jego zdolności, zainteresowania, uczucia, związane z muzyką i ogół tych wszystkich cech, które mają wpływ na jego stosunek do muzyki”. Ujmując problem w ten sposób, inaczej niż Seashore, Daniecka-Szopowa w centrum sytuuje człowieka, jego potrzeby i umiejętności, nie zaś samą muzykę. Z kolei Manturzewska (1995), w encyklopedycznym haśle „psychologia muzyki”, przedmiot zainteresowania tej nauki widzi jeszcze inaczej - w relacjach pomiędzy człowiekiem a muzyką oraz ich uwarunkowaniach na poziomie biopsychicznym i społeczno-kulturowym.

Próbując dookreślić, czym zajmuje się psychologia muzyki, powołując się na piśmiennictwo polskie warto przedstawić ciąg dalszy opinii Daneckiej-Szopowej (1960, s. 6), która stwierdza, że: „zagadnienia muzykalności i zdolności muzycznych zajmują centralne miejsce w tej nauce. Osobny dział to rozwój zdolności muzycznych i rozwój muzykalności, kształtowanie tych cech 
i wychowywanie”. Także cytowany już Wierszyłowski (1979), w swojej pracy koncentruje się na czynnościach muzycznych, uzdolnieniach w tym kierunku, metodach badań poziomu tychże uzdolnień, percepcji elementów muzycznych, funkcjach muzyki. Niejako podsumowując refleksję w tym zakresie Manturzewska (1995) grupuje powyższe zagadnienia w takie kategorie jak: psychologia zdolności muzycznych oraz psychologia percepcji muzyki.

Polska perspektywa nie odbiega od trendu światowego. Seashore (1967) kładzie nacisk na fizyczne wymiary dźwięku, dotyka też problemu myślenia, odczuwania oraz aktywizacji wyobraźni, a także procesu uczenia muzyki, talentu muzycznego oraz jego dziedziczności. Poruszając się w podobnej problematyce, nieco inną perspektywę przyjmuje Revesz (2001), klasyfikując rozważania dotyczące natury zjawisk dźwiękowych oraz ich percepcję jako psychologię dźwięku, za fundamentalne problemy psychologii muzyki uznając natomiast: muzykalność, talent muzyczny, rozwój umiejętności muzycznych, dziedziczenie umiejętności muzycznych, kreatywność, a także zagadnienie odbioru i produkcji muzycznej osób niesłyszących, patologie percepcji muzycznej oraz problem pochodzenie muzyki. Z kolei w zredagowanej przez Deutsch (1999) Psychology of Music znajdują się rozważania dotyczące natury dźwięków muzycznych, percepcji dźwięku i jego cech, mechanizmu grupowania i hierarchizacji bodźców, a także aspektów neurologicznych. Radocy i Boyle (1988) poszerzają ramy poszukiwań włączając w zakres publikacji Psychological Foundations of Musical Behavior problem preferencji muzycznych i ich kształtowania oraz refleksje nad funkcjami muzyki w kontekstach społecznych.

Zarówno Wierszyłowski, jak i Radocy i Boyle oraz Revesz dostrzegają obszar terapeutycznych oddziaływań muzyki. Problem ten, drugoplanowy dla psychologii muzyki, jest centralnym zagadnieniem muzykoterapii.

\subsection{MUZYKOTERAPIA}

Przed przytoczeniem kolejnych definicji muzykoterapii odwołać się znów trzeba do jej wspomnianego, praktyczno-naukowego dualizmu - terminem tym określa się zarówno praktykę terapeutyczną, jak i naukę o niej. Autor najszerszych chyba dywagacji nad uogólnioną naturą zjawiska, publikacji Defining Music Therapy - Keneth Bruscia (1998, s. 5-13) stwierdza, że dyscyplina ta jest szczególną hybrydą, łączącą same w sobie stwarzające trudności w definiowaniu muzykę i terapię; jednocześnie zawiera element nauki, sztuki i dziedziny relacji interpersonalnych. Jest ogromnie zróżnicowana, uwidacznia różnice kulturowe, wyrasta z odmiennych tradycji. 
Wydaje się, że ze względu na to właśnie silne zróżnicowanie, najlepiej określają ją definicje ogólne, jak propozycja Tadeusza Natansona, wedle której muzykoterapia jest „metodą postępowania, wielostronnie wykorzystującą wieloraki wpływ muzyki na psychosomatyczny ustrój człowieka” (Natanson, 1979, s. 51). Natanson zatem widzi narzędzie terapeutyczne w samej muzyce i jej potencjale. Bruscia (1998, s. 129) poszerza spektrum terapeutycznych możliwości muzykoterapii dostrzegając wartość terapeutyczną, obok muzycznych doświadczeń, także w relacjach powstających na ich gruncie. Jego definicja brzmi: „muzykoterapia to usystematyzowany proces interwencji w ramach którego terapeuta wspomaga klienta w osiąganiu zdrowia, używając doświadczeń muzycznych oraz relacji, które wykształcają się dzięki nim, jako dynamicznych sił umożliwiających zmiany” (Bruscia, 1998, s. 20).

W praktyce muzykoterapeutycznej prowadzący sesje terapeutyczne bazuje na wszelkich doświadczeniach związanych z muzyką: twórczości, improwizacji, wykonawstwie, percepcji. W działaniach wykorzystuje zarówno bezpośredni, wewnętrzny potencjał samej muzyki (muzyka jako terapia), jak i stosuje ją jako pretekst, inspirację do pozamuzycznych refleksji (muzyka w terapii).

Przedmiot muzykoterapii jako nauki będzie więc inny niż w przypadku psychologii muzyki, przede wszystkim ze względu na kliniczny wymiar dyscypliny. Ważnym obszarem będą tutaj działania o charakterze praktycznym, jak formy, modele i techniki oddziaływania. Badaniom w zakresie muzykoterapii podlegać musi zarówno proces terapeutyczny, jak i jego efektywność. Dla dyscypliny tej pytaniem o szczególnym znaczeniu będzie: w jaki sposób muzyka może zostać skutecznie zastosowana w sytuacji terapeutycznej (przy jednoczesnej świadomości, że fakt w jaki sposób muzyka i jej elementy wpływają na człowieka będzie miał ogromne znaczenie przy określaniu jej terapeutycznego potencjału).

W opisach dyscyplin uwidacznia się zasadnicza różnica między nimi - ich cel. Jest nim - w przypadku psychologii muzyki - poszukiwanie zasad i mechanizmów związanych z szeroko pojętym muzycznym funkcjonowaniem człowieka. Dla muzykoterapii, rozumianej jako praktyka, cel stanowi osiągnięcie poprawy funkcjonowania jednostki przy pomocy doświadczeń związanych z muzyką. Muzykoterapia jako nauka bada ten proces, a także zależności i zjawiska mające miejsce w jego ramach.

Próbując podsumować zależności między definicjami psychologii muzyki i muzykoterapii warto odwołać się jeszcze do jednego z najszerszych ogólnych źródeł wiedzy o muzyce - The New Grove Dictionary of Music and Musicians. W opracowaniu z 1980 r. znalazły się oba hasła, co ciekawe w dużej mierze 
autorstwa tej samej osoby - Natashy Spender². Psychologia muzyki opisana została z dużą szczegółowością, zajmując (włączając szeroką bibliografię) niemal 40 stron. Muzykoterapię zdefiniowano na jednej stronie, a wymieniona bibliografia jest bardzo skromna. We wprowadzeniu do problematyki psychologii muzyki wymienione zostają zagadnienia, którymi nauka ta się zajmuje; wśród nich - podobnie jak u Wierszyłowskiego odnaleźć można rolę muzyki w leczeniu fizycznych i psychicznych chorób. Jednak hasło „muzykoterapia” nie zawiera informacji o związku z psychologią muzyki. Wskazuje to na stan rozwoju obu dyscyplin w okresie tworzenia publikacji, a także na ówczesny brak - wydawałoby się naturalnej - refleksji na temat związków między nimi. Najnowsza wersja Grove’a dużo szerzej traktuje obie dyscypliny, jednak w dalszym ciągu widoczny jest rozdźwięk między nimi, szczególnie w zakresie dorobku badawczego. Niewątpliwie, psychologia muzyki jest zdecydowanie bardziej naukowo ugruntowaną dyscypliną. Z kolei muzykoterapia, będąca w okresie aktywnego rozwoju, wydaje się śmielej eksplorować zjawiska niedające się ująć w ramy ścisłych, pozytywistycznych rozważań.

\subsection{CZŁOWIEK W PSYCHOLOGII MUZYKI I MUZYKOTERAPII}

Przy określaniu przedmiotu psychologii muzyki koncentrowano się na muzyce i człowieku oraz interakcjach zachodzących między nimi w procesie twórczości i percepcji muzycznej. Podobnie, w centrum zainteresowania muzykoterapii znajduje się człowiek i muzyka. Kolejność użycia słów „człowiek” i „muzyka” została tutaj celowo odwrócona. Uznać można bowiem, za Seashorem, że punktem startowym psychologów muzyki jest samo zjawisko dźwiękowe, wraz z jego właściwościami; potem następują pytania o jego wpływ na człowieka. W muzykoterapii odwrotnie - wychodzi się od potrzeb człowieka, pod ich kątem badając muzykę i jej parametry. Sam człowiek w obu dyscyplinach oznacza też kogo innego. O ile w większości przypadków dla psychologa muzyki wspomnianym człowiekiem będzie uogólniona postać mieszcząca się w zdrowotnej normie, często dodatkowo charakteryzująca się wyjątkowym, ponadprzeciętnym talentem muzycznym, o tyle muzykoterapeuta pochyli się nad człowiekiem w jakiś sposób od normy odbiegającym, wymagającym interwencji terapeutycznej.

Dla psychologa muzyki interesujący jest człowiek w jego muzycznym profilu. Inne dziedziny życia nie znajdą się w spektrum badań, chyba że w relacji do funkcjonowania muzycznego. Dla muzykoterapeuty - przeciwnie. Ogólne

\footnotetext{
${ }^{2}$ Tekst dotyczący psychologii muzyki uzupełniony został przez Rosamund Shuter-Dyson.
} 
funkcjonowanie i jego szeroko pojęta poprawa, stanowią stałą perspektywę. Muzyka i funkcjonowanie muzyczne czy muzyczne doświadczenia wszelkiego typu są tu elementami kluczowymi, jednak nie jako fenomeny same w sobie, lecz jako narzędzia prowadzące do poprawy funkcjonowania ogólnego, w sytuacjach pozamuzycznych.

Wśród populacji, które poddawane są szczególnej obserwacji psychologów muzyki, znajdują się często osoby zajmujące się muzyką zawodowo bądź dzieci i młodzież szkolące się w tym kierunku, także wykazujące wybitne zdolności. Przedmiotem dociekań jest sposób przyswajania wiedzy i umiejętności muzycznych, zarówno w zakresie wykonawstwa czy twórczości, jak i odbioru muzyki. W muzykoterapii tyleż wspomniana grupa, co i proces uczenia muzyki odsunięte są na daleki plan. Stopień muzykalności, talent muzyczny i muzyczne umiejętności nie są tutaj szczególnie istotne. Muzykoterapia skierowana jest do wszystkich wymagających pomocy, bez względu na wymienione cechy. Poniższa tabela ukazuje uproszczoną charakterystykę człowieka będącego w centrum zainteresowania obu dyscyplin.

Tabela 1. Charakterystyka człowieka

\begin{tabular}{ll}
\hline Psychologia muzyki & Muzykoterapia \\
\hline Człowiek & Człowiek \\
- każdy & - potrzebujący wsparcia \\
- szczególnie uzdolniony muzycznie & - o każdym stopniu uzdolnienia \\
- funkcjonowanie muzyczne & - funkcjonowanie muzyczne jako narzędzie funkcjo- \\
& nowania pozamuzycznego \\
\hline
\end{tabular}

Źródło: Opracowanie własne.

\section{PSYCHOLOGIA MUZYKI I MUZYKOTERAPIA W KLASYFIKACJI NAUK}

Przy rozważaniu zależności istniejących pomiędzy psychologią muzyki a muzykoterapią istotnym wydaje się umiejscowienie obu dyscyplin w ogólnej klasyfikacji nauk. Rozważania te wymagają poprzedzenia uściśleniem terminu „muzykoterapia”; odwołując się do cytowanej we wstępie wypowiedzi Natansona (1979), w tym przypadku dotyczył on będzie przede wszystkim wiedzy, nauki o praktycznej działalności, nie zaś jej samej. W praktycznej działalności elementem nieodzownym jest wątek artystyczny, sztuka, niepodlegająca naukowym klasyfikacjom.

Ze względu na interdyscyplinarny charakter psychologii muzyki i muzykoterapii umieszczenie tych nauk w konkretnych kategoriach nie jest proste i oczy- 
wiste. W ogólnym, podstawowym podziale uzasadnione wydaje się ich wspólne usytuowanie w grupie nauk empirycznych, społecznych, wraz z psychologią i pedagogiką. Jednocześnie jednak część działalności muzykoterapeutycznej i dotyczącej psychologii muzyki pozostaje w ścisłym związku z naukami medycznymi, akustyką, neurobiologią, należącymi do nauk przyrodniczych.

By uzmysłowić sobie interdyscyplinarność obu obszarów, warto przyjrzeć się klasyfikacji Kamińskiego (1992), który dzieli nauki na:

1. nauki o przedmiotach traktowanych bardziej uniwersalnie, w tym: a) nauki formalne, b) nauki realne, filozofia

2. nauki o przedmiotach traktowanych bardziej partykularnie, w tym: a) przyrodoznawstwo, m.in. fizyka, chemia, biologia, kosmologia, b) nauki o kulturze materialnej - wśród nich technika, rolnictwo, a także medycyna, c) humanistyka, m.in. nauki o człowieku i społeczeństwie, nauki prawne, filologia, nauki o poszczególnych dziedzinach kultury.

Wydaje się, że zarówno psychologia muzyki, jak i muzykoterapia w tym podziale znajdą się w grupie drugiej, zapewne w kategorii humanistyka, choć ich pozycja w tym miejscu budzi jednak pewne wątpliwości. Widoczny jest bowiem pomostowy charakter obu dziedzin, wykraczających z humanistyki w kierunku przyrodoznawstwa, a także, w przypadku muzykoterapii, ze względu na związek z medycyną, w kierunku nauk o kulturze materialnej.

Już sam wspólny dla omawianych dyscyplin człon - psychologia - wymyka się popularnemu, prostemu podziałowi na nauki przyrodnicze i humanistyczne. Grobler (2006) zauważa, że w naukach przyrodniczych brak jest miejsca na obecną w psychologii intencjonalność, co wyklucza ją z tej kategorii, bazującej na związkach przyczynowo-skutkowych. Jednocześnie, definiując humanistykę jako naukę o wytworach ludzkich stwierdza, że i do nie niej nie kwalifikuje się nauka badająca stany i czynności psychiczne (s. 240).

Gdy rozpatruje się charakter wybranych dyscyplin pod kątem ich dorobku badawczego, różnice między nimi stają się wyraźniejsze. O ile psychologia muzyki, podobnie jak cała psychologia, zdaje się poszukiwać ogólniejszych praw, o tyle wyjaśnienia na gruncie muzykoterapii często posiadają bardziej zindywidualizowany profil, gdyż ich celem jest szczegółowe rozpoznanie konkretnej, terapeutycznej sytuacji i dokonanie jej opisu. Można zatem stwierdzić, że ze względu na podejmowane próby formułowania praw psychologia muzyki sytuuje się w nurcie nomotetycznym, zaś muzykoterapia - nierzadko badająca jednorazowe, niepowtarzalne fakty - przyjmuje bardziej idiograficzny charakter. Choć w obu przypadkach zdarzają się sytuacje odwrotne (psychologia muzyki bada również wyjątkowe, jednostkowe, wybitne talenty muzyczne, a muzykoterapia 
poszukuje generalnych zjawisk, uzasadniających jej skuteczność) wydaje się, że w całościowym obrazie przychylają się one do alternatywnych stanowisk.

Z takim uwarunkowaniem wiążą się także wybory dokonywane w zakresie metodologii badań. Osiągnięcia psychologii muzyki w tym zakresie to - podobnie zresztą jak w psychologii ogólnej - przede wszystkim badania ilościowe, często o eksperymentalnym charakterze, z zastosowaniem restrykcyjnych kryteriów pełnej randomizacji prób, prowadzone w oparciu o różne plany badawcze. Muzykoterapia, mająca więcej wspólnego z psychoterapią, wciąż w dużej mierze bazuje na studiach przypadków oraz rozważaniach jakościowych, choć faktem jest, że i w tej dyscyplinie liczba przeprowadzanych eksperymentów wzrasta. Muzykoterapeuci obawiają się, że na skutek konieczności spełnienia obiektywnych, ostrych kryteriów badań eksperymentalnych (jak przede wszystkim kontrola zmiennych), muzyka badana przez psychologów muzyki, rozłożona na poszczególne składniki traci swój fundamentalny sens wynikający z kompleksowości właśnie. Argumentują, że badanie poszczególnych komponentów nie prowadzi wcale do poznania całościowego jej fenomenu i zarzucają eksperymentom wyrywkowość i rozmijanie się z sednem zjawiska (Pavlicevic, 2005). Psycholodzy muzyki z kolei, dostrzegając ogromną ilość niekontrolowanych zmiennych obecnych w procesie terapeutycznym sugerują, że ze względu na bogatą interakcję między nimi proste pytanie: czy muzykoterapia działa, staje się pozbawione sensu, bo nie sposób konkretnie wskazać, co jest przyczyną tego działania (Sloboda, 1988, za: Bunt, 1999).

Różnice między psychologią muzyki a muzykoterapią są zauważalne także przy próbie sklasyfikowania ich pod kątem celu. Przy przyjęciu tego kryterium wskazuje się na dwie kategorie nauk: nauki teoretyczne, podstawowe, oraz praktyczne, stosowane. $\mathrm{W}$ tym pierwszym przypadku uzyskana wiedza stanowić ma wartość samą w sobie, w drugim - poznawanie ma służyć konkretnemu działaniu. I znów niemożliwe jest umieszczenie omawianych dyscyplin w wyłącznie jednej kategorii. Można jednak uznać, że charakter muzykoterapii jest bardziej praktyczny, stosowany, ukierunkowany na konkretne działanie, choć przecież także w psychologii muzyki nierzadko celem badań jest bezpośrednio usprawnienie procesu rozpoznawania talentu muzycznego czy wspieranie rozwoju muzycznego dziecka. W takiej systematyzacji muzykoterapia niemal w pełni mieści się w drugiej kategorii, podczas gdy psychologia muzyki swą działalnością łączy je obie. Podział według tego kryterium jest, przynajmniej w ściśle spolaryzowanej formie, sztuczny, a jednoznaczna klasyfikacja w jego ramach jakiejkolwiek nauki - zapewne niemożliwa. Traktując go jednak elastycznie, wielu uznaje, że wszystkie nauki empiryczne mają jednocześnie wymiar teoretyczny i praktyczny; inni - że teoria 
i praktyka leżą na dwóch końcach skali, zaś nauki sytuują się w całej rozciągłości tego kontinuum (Kamiński 1992, s. 301). Przyjmując takie założenie, uznać można, że wybierając spośród dwóch dyskutowanych dyscyplin, muzykoterapia bliższa jest praktycznemu końcowi osi.

Chcąc uogólnić to, czym jest przedmiot badań w psychologii muzyki i muzykoterapii, odwołać się można jeszcze do ogólnego opisu przedmiotu badań naukowych, definiowanego jako zbiór elementów, zjawisk określonego rodzaju (tzw. uniwersum) oraz wielkości (cech) charakteryzujących te obiekty wraz z zależnościami zachodzącymi pomiędzy nimi (Nowak, 1977, s. 31). W obu przypadkach do uniwersum należeć będą człowiek i muzyka. Jednakże cechy tychże elementów będą różne, a zależności między nimi poddawane badaniom - odmienne.

\section{PSYCHOLOG MUZYKI I MUZYKOTERAPIA - NAUKOWIEC I ARTYSTA?}

Jak wspomniano, zasadniczą różnicą wynikającą z teoretycznego i praktycznego charakteru dyscyplin, czy może raczej z akademickości jednej i użytkowości drugiej, jest stosunek specjalistów do sztuki muzycznej. Dla psychologa muzyki, podobnie jak dla muzykologa czy teoretyka, jest ona zjawiskiem zewnętrznym, które z dystansu poddaje refleksji. Muzykoterapeuta musi być także jej twórcą. Psycholog muzyki powinien oczywiście posiadać szeroką wiedzę na temat twórczości muzycznej i procesów z nią związanych, niekoniecznie jednak posługiwać się nią będzie w praktyce. W procesie terapeutycznym, szczególnie przy zastosowaniu technik aktywnych, muzykoterapeuta korzysta ze swoich artystycznych zasobów, zarówno w zakresie umiejętności gry na instrumentach czy śpiewu, jak i podstaw kompozycji, aranżacji, prowadzenia zespołu. By potencjał terapeutyczny mógł się w pełni zrealizować, poziom działań o charakterze twórczym musi być wysoki, tak aby umożliwić klientowi przeżycie estetyczne i satysfakcję. Profesjonalne, przekonujące umiejętności artystyczne muzykoterapeuty są warunkiem nieodzownym dla maksymalnej realizacji potencjału procesu muzykoterapii.

\section{MUZYKA WEDŁUG PSYCHOLOGA MUZYKI, MUZYKA WEDŁUG MUZYKOTERAPEUTY}

Muzyka, według podstawowej, najprostszej definicji, to sztuka organizacji dźwięków w przebiegu czasowym. Takie postawienie sprawy dla specjalistów, artystów i naukowców jest jednak dalekie od wyczerpującego opisu. Czym zatem jest 
muzyka dla psychologa muzyki i muzykoterapeuty? Wydaje się, że jedni i drudzy w dużym stopniu traktują zjawisko podobnie - szeroko, bez wnikania w szczegółowe estetyczne dywagacje. Psychologów muzyki zastanawia, w jaki sposób człowiek odróżnia dźwiękowe zjawiska muzyczne od niemuzycznych. W jaki sposób słuchamy muzyki? Jak przy jej odbiorze działają mechanizmy grupowania? Jaki jest jej związek z emocjami?

Muzykoterapeuta wskazanym pytaniom nie poświęca aż tak wiele uwagi. Zwraca uwagę na funkcjonalną stronę problemu. Nie zastanawia się, czy dane zjawisko dźwiękowe spełnia bardziej szczegółowe kryteria muzyki, raczej sprawdza, czy może ono pomóc w osiągnięciu terapeutycznego celu. Czy zatem muzykoterapia to raczej dźwiękoterapia? Ze względu na szerokie spektrum technik i zjawisk stosowanych w tym sposobie oddziaływania drugie określenie, choć adekwatne do opisu niektórych z nich, wydaje się nadmiernie ograniczające. Większość doświadczeń proponowanych w procesie terapeutycznym wiąże się jednak ze zorganizowanym przebiegiem dźwięków (choć stopień organizacji może być bardzo różny). Gdyby definicję muzyki poszerzać o kryteria estetyczne, termin muzykoterapia mógłby zostać uznany za nadużycie, jeśli jednak sztukę dźwięków rozumiemy w podstawowy sposób, jest ono w pełni uprawnione.

\section{WZAJEMNE INSPIRACJE - PODSUMOWANIE}

Z pewnością działania muzykoterapeutyczne mogą i powinny czerpać z odkryć psychologii muzyki. Wheeler (2015) stwierdza, że psycholodzy muzyki dostarczają podstaw wielu praktycznym działaniom muzykoterapeutów. Jako ilustrację tego procesu podaje badania wskazujące na potencjał rytmu w zakresie organizacji ruchu. Dzięki świadomości tego potencjału muzykoterapeuta może odpowiednio adaptować i dobierać skuteczne techniki w pracy z pacjentami z zaburzeniami w sferze motoryki.

Wydaje się jednak, że także psychologia muzyki zyskać może w kontakcie z muzykoterapią. Przykładem uzupełnienia się tych dwóch perspektyw są rozdziały dotyczące zagadnienia interesującego dla obu dyscyplin, mianowicie muzyki i emocji, umieszczone w książce Music and emotion. Theory and research. Psycholodzy muzyki - Juslin i Sloboda (2001) poszukują źródeł emocji łączących się z muzyką. Zauważają, że mogą one być pochodną czysto muzycznych struktur lub mieć odniesienia zewnętrzne. Wewnętrzne elementy czy struktury muzyczne mające wpływ na rodzaj percypowanych emocji to np. tempo, rytm, tryb, ambitus melodyczny, środki harmoniczne (Gabrielsson, Lidstrom, 2001). W drugiej kate- 
gorii (źródła zewnętrzne) umieszczono źródła ikoniczne (iconic) i skojarzeniowe (associative). Te pierwsze wynikają z formalnego podobieństwa między strukturą muzyczną i daną sytuacją. Głośność i szybkie tempo mogą być cechami utworu muzycznego i wydarzenia o wysokim stopniu energii. Wysoka energetyczność z kolei wywołać może uczucie pobudzenia, ekscytację.

Muzykoterapeuci - Bunt i Pavlicevic (2001) - odnosząc się do klasyfikacji psychologów muzyki, wskazują od razu na modele muzykoterapeutyczne bądź wybrane techniki, bazujące na odmiennych źródłach emocji. Działania dotyczące wspierania funkcjonowania osób starszych lub z zaburzeniami pamięci często odwołują się do skojarzeniowych źródeł emocji rodzących się przy słuchaniu muzyki. Poprzez znajome struktury muzyczne odnaleźć można drogę do zapomnianych treści czy stanów. Dzięki źródłom ikonicznym możliwe jest stosowanie improwizacji o charakterze referencjalnym; ukierunkowanie gry w stronę pozamuzycznych skojarzeń umożliwia eksplorację stanów emocjonalnych, ich dynamiki i parametrów (np. improwizacja na temat burzy może mieć wspólne cechy z odgrywaniem złości). Model muzykoterapii receptywnej, znany jako kierowane wyobrażenia z muzyką (guided imagery and music), wykorzystuje z kolei interakcję pomiędzy wszystkimi trzema źródłami emocji w muzyce. Słuchając muzyki, klient pod jej wpływem udaje się w „podróż” w głąb siebie, doświadczając wrażeń i emocji budowanych na kilku poziomach.

Uzupełniająca się refleksja wynikająca ze specyfiki tych dwóch dziedzin dotyczyć może wielu zagadnień. Mechanizmy psychiczne i reakcje fizjologiczne stanowiące zaplecze muzycznej percepcji i twórczości są obszarem badań psychologów muzyki; rezultaty tych prac przyczynią się niewątpliwie do wzrostu świadomości muzykoterapeutów, usprawniając proces terapeutycznych oddziaływań. Badania wskazujące na bezpośrednie związki pomiędzy zmianami w elementach muzyki a reakcjami na poziomie umysłu lub mózgu pomogą doprecyzować dobór najodpowiedniejszego dla sytuacji terapeutycznej repertuaru muzycznego. Podobnie, z doświadczeń dotyczących kształtowania się preferencji muzycznych muzykoterapeuci powinni wyciągać wnioski mające wpływ na formułowanie terapeutycznych programów. Z drugiej strony muzykoterapia, obejmując złożony, skomplikowany zakres holistycznych oddziaływań i będąc w opozycji do szczegółowych badań psychologicznych abstrahujących drobne elementy muzycznego fenomenu, może przyczynić się do poszerzenia perspektywy psychologii muzyki.

Kontakt pomiędzy psychologią muzyki i muzykoterapią może wzbogacić obie dyscypliny także w obszarze metodologii badań. W tym zakresie zdecydowanie bardziej rozwinięte są poczynania psychologii muzyki, bazującej w dużej mierze na eksperymentach. Korzystając z takich doświadczeń muzykoterapia mogłaby 
udoskonalić swoje narzędzia badawcze. Wydaje się, że w odwrotnym kierunku zainteresowanie metodologiczne również jest uzasadnione. Muzykoterapia wykorzystuje ciekawe podejścia jakościowe, łącząc elementy naukowe z humanistyczną refleksją, mogące zapewne wnieść nowe jakości w psychologiczne podejście do muzyki.

Różnice metodologiczne oraz odmienność założeń tkwiących u podstaw obu dyscyplin bywają powodem nieporozumień między psychologami muzyki i muzykoterapeutami; mogą jednak przybrać wysoce konstruktywną postać (Bunt, Cross, Clarke, Hoskyns, 1988). Mając na uwadze fakt, że poruszając się po bliskich obszarach dyscypliny mogą istotnie wzbogacić się wzajemnie, współpraca między nimi wydaje się bardzo pożądana.

\section{ZAKOŃCZENIE}

Psychologia muzyki i muzykoterapia to dwie różne dyscypliny z wieloma punktami stycznymi, szczególnie w zakresie akademickiej refleksji.

Psychologia muzyki interesuje się człowiekiem w jego ogólności lub w jego muzycznym profilu. Muzykoterapia zajmuje się człowiekiem potrzebującym terapii. Psycholog muzyki to naukowiec. Muzykoterapeuta posiadać musi także umiejętności artystyczne. Psycholog bada muzykę i człowieka, muzykoterapeuta praktyk, często muzykę tworzy, a z człowiekiem wchodzi w bezpośrednią relację.

W badaniach psycholodzy muzyki przeprowadzają rygorystyczne eksperymenty, wskazujące na rezultaty, które ulec mogą generalizacji; dzięki nim zyskują wiedzę o mechanizmach rządzących muzycznym funkcjonowaniem człowieka. Muzykoterapeuci, choć coraz częściej sięgają po podobne narzędzia i metody, nierzadko zorientowani są bardziej na subiektywne, indywidualne cele i skutki prowadzonych działań terapeutycznych, częściej odnajdują się w jakościowych modelach badawczych, nieukazujących ogólnych praw, lecz jedynie jednostkowy wymiar prowadzonych działań.

Niewątpliwie, psycholodzy muzyki i muzykoterapeuci mogą się wzajemnie wzbogacić; psychologia muzyki przyczynić się może do zwiększenia efektywności i świadomości prowadzonej terapii, zaś praktyka muzykoterapeutyczna może zainspirować badaczy do podejmowania kolejnych wątków, zadawania pytań i eksplorowania zagadnień. 


\section{Literatura:}

Brown, J. (red.), (2007). Western music and race. Cambridge: University Press.

Brown, S., Volgsten, U. (red.), (2006). Music and Manipulation. On the Social Uses and Social Control of Music. New York, London: Berghahn Books.

Bruscia, K. (1998). Defining music therapy. Gilsum: Barcelona Publishers.

Bunt, L. (1999) An art. Beyond words. Routledge, London \& New York.

Bunt, L., Cross, I., Clarke, E., Hoskyns, S. (1988). A discussion on the relationships between music therapy and the psychology of music. Psychology of Music, 16 (1), s. $62-70$.

Curtis, B. (2008). Music Makes the Nation: Nationalist Composers and Nation Building in Nineteenth-Century Europe. Amherst, Cambria Press.

Danecka-Szopowa, K. (1960). Wybrane zagadnienia z psychologii muzyki. Warszawa: Centralny Ośrodek Pedagogiczny Szkolnictwa Artystycznego.

Deutsch, D. (red.), (1999). The psychology of music, 2d ed. New York: Academic Press. Grobler, A. (2006). Metodologia nauk. Kraków: Wydawncitwo Aureus, Wydawnictwo Znak.

Hodges, D. (2003). Music Psychology and Music Education: What's the Connection? W: Research Studies in Music Education, 2003. 21, s. 31-44.

Juslin, P. \& Sloboda, J., red. (2001). Music and emotion. New York: Oxford University Press.

Kamiński S. (1992). Nauka i metoda. Pojęcie nauki i klasyfikacja nauk. Lublin: Towarzystwo naukowe KUL.

Manturzewska, M. (1995). Psychologia muzyki. W: Encyklopedia Muzyki. Warszawa: PWN.

Natanson, T. (1979). Wstęp do nauki o muzykoterapii. Wrocław-Warszawa-KrakówGdańsk: Zakład Narodowy im. Ossolińskich.

Nowak, L. (1977). Wstęp do idealizacyjnej teorii nauki. Warszawa: PWN.

O’Connel, J., Castello-Branco, S. (red.), (2010). Music and conflict. Chicago: University of Illinois Press.

Patel, A. (2008). Music, language and the brain. New York: Oxford University Press.

Pavliceviv, M. (2005). Music Therapy in Context: Music, Meaning and Relationship. Londyn: Jessica Kingsley Publishers.

Révész, G. (1954). Introduction to the psychology of music. Norman: University of Oklahoma Press.

Sadie, S., Grove, G. (red.), (1980). The new Grove dictionary of music and musicians. Londyn: Oxford University Press.

Seashore, C. (1967). Psychology of music. Mineola: Dover Publications.

Silbermann, A. (1999). Sociology of Music. London: Routledge.

Sloboda, J. (1988). A discussion of Case Study Research in Psychology of Music: implications for music therapy. W: The case study as research. London: The City University.

Thaut M. (2005). Rhythm, Music and the Brain: Scientific Foundations and Clinical Applications. New York: Routledge.

Wierszyłowski, J. (1979). Psychologia muzyki. Warszawa: PWN.

Zatorre, R., Peretz, I. (red.), (2001). The biological foundations of music. New York: New York Academy of Sciences. 